\title{
TWO NOVEL TCPP PORPHYRINIC COMPOUNDS: IN SITU SYNTHESES, CHARACTERIZATION AND REACTION MECHANISM
}

\author{
DING-WA ZHANG ${ }^{l}, W E N-T O N G C H E N^{1,2,31}$ \\ 'Institute of Applied Chemistry, School of Chemistry and Chemical Engineering, Jinggangshan University, Ji'an, Jiangxi 343009, China \\ ${ }^{2}$ Key Laboratory of Jiangxi Province for Persistant Pollutants Control and Resources Recycle (Nanchang Hangkong University), \\ Nanchang, Jiangxi 330000, China \\ ${ }^{3}$ State Key Laboratory of Structural Chemistry, Fujian Institute of Research on the Structure of Matter, Chinese Academy of Sciences, \\ Fuzhou, Fujian 350002, China
}

\begin{abstract}
Two novel porphyrinic compounds, $\left\{\mathrm{Zn}\left[\mathrm{TCPP}\left(\mathrm{CH}_{2} \mathrm{CH}_{3}\right)_{2}\left(\mathrm{CH}_{3}\right)_{2}\right]\right\}_{n}$ (1) and TCPP $\left(\mathrm{CH}_{3}\right)_{4}$ (2) (TCPP = meso-tetra(4-carboxyphenyl)porphyrin), with the TCPP $\left(\mathrm{CH}_{2} \mathrm{CH}_{3}\right)_{2}\left(\mathrm{CH}_{3}\right)_{2}$ and TCPP $\left(\mathrm{CH}_{3}\right)_{4}$ generated in situ, have been synthesized via a solvothermal reaction and structurally characterized by single-crystal $\mathrm{X}$-ray diffraction. Compound $\mathbf{1}$ is characteristic of a two-dimensional (2-D) coordination polymer, based on the zinc ion coordinating to four nitrogen atoms and two oxygen atoms. Compound 1 possesses a large void space $\left(220 \AA^{3}\right)$ corresponding to $4.6 \%$ of the unit-cell volume. Compound 2 is characterized by an isolated structure. The reaction mechanism of preparing both compounds was explored. The photoluminescence properties, FT-IR, UV-vis absorption spectra, fluorescence lifetime and fluorescence quantum yield of TCPP were also reported.
\end{abstract}

Keywords: esterification, in situ, porphyrin, TCPP, zinc

\section{INTRODUCTION}

An in situ reaction can possibly lead to the formation of a new compound with a novel structure or interesting properties. ${ }^{1,2}$ In situ reactions under solvothermal conditions have recently obtained a lot of attentions and many novel compounds have been synthesized thus far. ${ }^{3-456}$ Porphyrins are one of the most widely studied compounds and the important roles played in nature have been found for several decades. Lots of efforts have been devoted to chemically transform a porphyrin into a derivative with reformative features that may offer it a possibly practical application..$^{7-89}$ Numerous organic groups have so far been used to transform porphyrins by decorating their periphery. However, among which, the esterification of a porphyrin has been rarely reported. TCPP is a large, rigid and square-planar symmetrical molecule with divergent carboxylic groups that could be possibly esterified. Our recent efforts are mainly focusing on the study of porphyrinic compounds, ${ }^{10-111213}$ including the $i n$ situ reactions of TCPP under solvothermal conditions. We report herein the in situ syntheses, characterization and properties of two novel porphyrinic compounds, $\left\{\mathrm{Zn}\left[\mathrm{TCPP}\left(\mathrm{CH}_{2} \mathrm{CH}_{3}\right)_{2}\left(\mathrm{CH}_{3}\right)_{2}\right]\right\}_{n}(1)$ and $\mathrm{TCPP}\left(\mathrm{CH}_{3}\right)_{4}(2)(\mathrm{TCPP}=$ meso-tetra(4carboxyphenyl)porphyrin). It is noteworthy that the TCPP $\left(\mathrm{CH}_{2} \mathrm{CH}_{3}\right)_{2}\left(\mathrm{CH}_{3}\right)_{2}$ and $\operatorname{TCPP}\left(\mathrm{CH}_{3}\right)_{4}$ were generated in situ. The photoluminescence properties, FT-IR, UV-vis absorption spectra, fluorescence lifetime, and fluorescence quantum yield of TCPP are also reported in this work.

\section{EXPERIMENTAL}

All reactants of analytical reagent grade quality are obtained commercially and used without further purification. FT-IR spectrum is performed with a $\mathrm{KBr}$ disc in the range of $400-4000 \mathrm{~cm}^{-1}$ on a PE Spectrum-One spectrometer. The photoluminescent spectra are carried out at room temperature using solidstate samples on a JY FluoroMax-3 spectrometer. The UV-vis absorption spectroscopies were conducted at room temperature on a computer-controlled Hewlett Packard 89090A UV-vis spectrometer with the wavelength range of $190-1100 \mathrm{~nm}$. Measurements of emission quantum yield of powdered samples were carried out on a Hamamatsu C9920-0X(PMA-12) U6039-05 fluorescence spectrofluorometer. Fluorescence lifetime measurements were carried out using a Photon Technology International GL-3300 nitrogen laser.

Synthesis and characterization of $\left\{\mathrm{Zn} / \mathrm{TCPP}\left(\mathrm{CH}_{2} \mathrm{CH}_{3}\right)_{2}\left(\mathrm{CH}_{3}\right)_{2}\right\}_{n}$ (1): Compound 1 was prepared by mixing $\mathrm{ZnSO} \cdot \mathrm{H}_{2} \mathrm{O}(0.2 \mathrm{mmol}, 35.8 \mathrm{mg})$, TCPP $(0.2 \mathrm{mmol}, 158.0 \mathrm{mg}), 5 \mathrm{~mL}$ methanol and $5 \mathrm{~mL}$ ethanol in a $25 \mathrm{~mL}$ Teflonlined stainless steel autoclave and heating the mixture at $443 \mathrm{~K}$ for 7 days. After cooling slowly the mixture to room temperature at $6 \mathrm{~K} / \mathrm{h}$, red crystals suitable for X-ray analysis were obtained.
Synthesis and characterization of $\mathrm{TCPP}\left(\mathrm{CH}_{3}\right)_{4}$ (2): Compound 2 was synthesized by loading TCPP $(0.1 \mathrm{mmol}, 79.0 \mathrm{mg})$ and $15 \mathrm{~mL}$ methanol into a $25 \mathrm{~mL}$ Teflon-lined stainless steel autoclave and heating the autoclave at $443 \mathrm{~K}$ for 7 days. After cooling slowly the mixture to room temperature at $6 \mathrm{~K} / \mathrm{h}$, red crystals suitable for X-ray analysis were collected.

$X$-ray crystal structure determination: The intensity data set was collected on a Rigaku Mercury CCD X-ray diffractometer with graphite monochromated Mo-K $\alpha$ radiation $(\lambda=0.71073 \AA$ ) by using an $\omega$ scan technique. CrystalClear software was used for data reduction and empirical absorption corrections..$^{14}$ The structures were solved by the direct method using the Siemens SHELXTL ${ }^{\mathrm{TM}}$ Version 5 package of crystallographic software. ${ }^{15}$ The difference Fourier maps based on these atomic positions yield the other non-hydrogen atoms. The hydrogen atom positions were generated theoretically and allowed to ride on their respective parent atoms and included in the structure factor calculations with assigned isotropic thermal parameters but were not refined. The structures were refined using a full-matrix least-squares refinement on $F^{2}$. All atoms were refined anisotropically. A summary of crystallographic data and structure analysis is listed in Table 1, and selected bond distances and bond angles for compound $\mathbf{1}$ are given in Table 2. Crystallographic data for the structural analysis have been deposited with the Cambridge Crystallographic Data Centre, CCDC No. 893021 (1) and 1474473 (2). Copies of this information may be obtained free of charge from the Director, CCDC, 12 Union Road, Cambridge, CBZ 1EZ, UK (Fax: +44-1223-336033; email: deposit@ccdc. cam.ac.uk or www:http://www.ccdc. cam.ac.uk).

\section{RESULTS AND DISCUSSION}

The raw material is TCPP, but $\operatorname{TCPP}\left(\mathrm{CH}_{2} \mathrm{CH}_{3}\right)_{2}\left(\mathrm{CH}_{3}\right)_{2}$ and $\operatorname{TCPP}\left(\mathrm{CH}_{3}\right)_{4}$ exists in compounds $\mathbf{1}$ and $\mathbf{2}$, respectively. This suggests that in situ reactions have occurred under solvothermal environments. Single-crystal X-ray diffraction analysis reveals that compound $\mathbf{1}$ is characteristic of a 2-D structure, containing neutral $\left\{\mathrm{Zn}\left[\mathrm{TCPP}\left(\mathrm{CH}_{2} \mathrm{CH}_{3}\right)_{2}\left(\mathrm{CH}_{3}\right)_{2}\right]\right\}_{n}$ layers. Compound $\mathbf{1}$ crystallizes in the space group $\mathrm{C} 2 / \mathrm{c}$ of the monoclinic system with four formula units in a cell. All crystallographic independent atoms, except for zinc, are in general positions. An ORTEP drawing of $\mathbf{1}$ with $30 \%$ thermal ellipsoids is shown in Fig. 1. 
Table 1. Summary of crystallographic data and structure analysis.

\begin{tabular}{|l|c|c|}
\hline Compound & $\mathbf{1}$ & $\mathbf{2}$ \\
\hline Formula & $\mathrm{C}_{54} \mathrm{H}_{40} \mathrm{~N}_{4} \mathrm{O}_{8} \mathrm{Zn}$ & $\mathrm{C}_{52} \mathrm{H}_{38} \mathrm{~N}_{4} \mathrm{O}_{8}$ \\
\hline$F w$ & 938.27 & 846.86 \\
\hline color & red & red \\
\hline Crystal size/mm & \\
\hline Crystal system & 0.420 .360 .23 & 0.120 .110 .06 \\
\hline Space group & monoclinic & monoclinic \\
\hline$a(\AA)$ & $C 2 / c$ & $P 2_{1} / c$ \\
\hline$b(\AA)$ & $26.549(7)$ & $8.597(4)$ \\
\hline$c(\AA)$ & $8.474(2)$ & $10.889(5)$ \\
\hline$\beta\left(^{\circ}\right)$ & $21.208(2)$ & $22.350(7)$ \\
\hline$V\left(\AA^{3}\right)$ & $90.49(1)$ & $101.506(12)$ \\
\hline$Z$ & $4771.1(18)$ & $2050.2(15)$ \\
\hline $2 \theta_{\text {max }}\left({ }^{\circ}\right)$ & 4 & 2 \\
\hline Reflections collected & 50 & 50 \\
\hline Independent, observed & 14096 & 10441 \\
reflections $\left(R_{\text {int }}\right)$ & $4002,1286(0.0830)$ & 3603,3063 \\
\hline$d_{\text {calc. }}\left(\mathrm{g} / \mathrm{cm}^{3}\right)$ & & $(0.0405)$ \\
\hline$\mu\left(\mathrm{mm}{ }^{-1}\right)$ & 1.306 & 1.372 \\
\hline$T(\mathrm{~K})$ & 0.574 & 0.094 \\
\hline$F(000)$ & 123 & 123 \\
\hline$R_{1}, w R_{2}$ & 1944 & $0.0648,0.1662$ \\
\hline$S$ & $0.0732,0.0951$ & $0.662,-0.318$ \\
\hline Largest and Mean $\Delta / \sigma$ & 0.973 & \\
\hline$\Delta \rho($ max, min$)\left(\mathrm{e} / \AA^{3}\right)$ & 0,0 & $0.577,-0.273$ \\
\hline & & \\
\hline
\end{tabular}

Table 2. Selected bond lengths $(\AA)$ and bond angles $\left(^{\circ}\right)$ for compound $\mathbf{1}$.

\begin{tabular}{|c|c|c|c|}
\hline $\mathrm{Zn}(1)-\mathrm{N}(1)$ & $2.010(3)$ & $\mathrm{N}(2)-\mathrm{Zn}-\mathrm{N}(1) \# 1$ & $89.12(10)$ \\
\hline $\mathrm{Zn}(1)-\mathrm{N}(1) \# 1$ & $2.010(3)$ & $\mathrm{N}(1)-\mathrm{Zn}-\mathrm{N}(1) \# 1$ & $180.0(2)$ \\
\hline $\mathrm{Zn}(1)-\mathrm{N}(2)$ & $1.975(3)$ & $\mathrm{N}(2) \# 1-\mathrm{Zn}-\mathrm{O}(2) \# 2$ & $84.75(9)$ \\
\hline $\mathrm{Zn}(1)-\mathrm{N}(2) \# 1$ & $1.975(3)$ & $\mathrm{N}(2)-\mathrm{Zn}-\mathrm{O}(2) \# 2$ & $95.25(9)$ \\
\hline $\mathrm{Zn}(1)-\mathrm{O}(2) \# 2$ & $2.628(2)$ & $\mathrm{N}(1)-\mathrm{Zn}-\mathrm{O}(2) \# 2$ & $96.46(9)$ \\
\hline $\mathrm{Zn}(1)-\mathrm{O}(2) \# 3$ & $2.628(2)$ & $\mathrm{N}(1) \# 1-\mathrm{Zn}-\mathrm{O}(2) \# 2$ & $83.54(9)$ \\
\hline & & $\mathrm{N}(2) \# 1-\mathrm{Zn}-\mathrm{O}(2) \# 3$ & $95.25(9)$ \\
\hline $\mathrm{N}(2) \# 1-\mathrm{Zn}-\mathrm{N}(2)$ & $180.0(2)$ & $\mathrm{N}(2)-\mathrm{Zn}-\mathrm{O}(2) \# 3$ & $84.75(9)$ \\
\hline $\mathrm{N}(2) \# 1-\mathrm{Zn}-\mathrm{N}(1)$ & $89.12(10)$ & $\mathrm{N}(1)-\mathrm{Zn}-\mathrm{O}(2) \# 3$ & $83.54(9)$ \\
\hline $\mathrm{N}(2)-\mathrm{Zn}-\mathrm{N}(1)$ & $90.88(10)$ & $\mathrm{N}(1) \# 1-\mathrm{Zn}-\mathrm{O}(2) \# 3$ & $96.46(9)$ \\
\hline $\mathrm{N}(2) \# 1-\mathrm{Zn}-\mathrm{N}(1) \# 1$ & $90.88(10)$ & $\mathrm{O}(2) \# 2-\mathrm{Zn}-\mathrm{O}(2) \# 3$ & $180.00(12)$ \\
\hline
\end{tabular}
$z-1 / 2$.

Symmetry codes: \#1 -x+1/2,-y+1/2,-z; \#2 -x+1/2, $y-1 / 2,-z+1 / 2 ; \# 3 x,-y+1$,

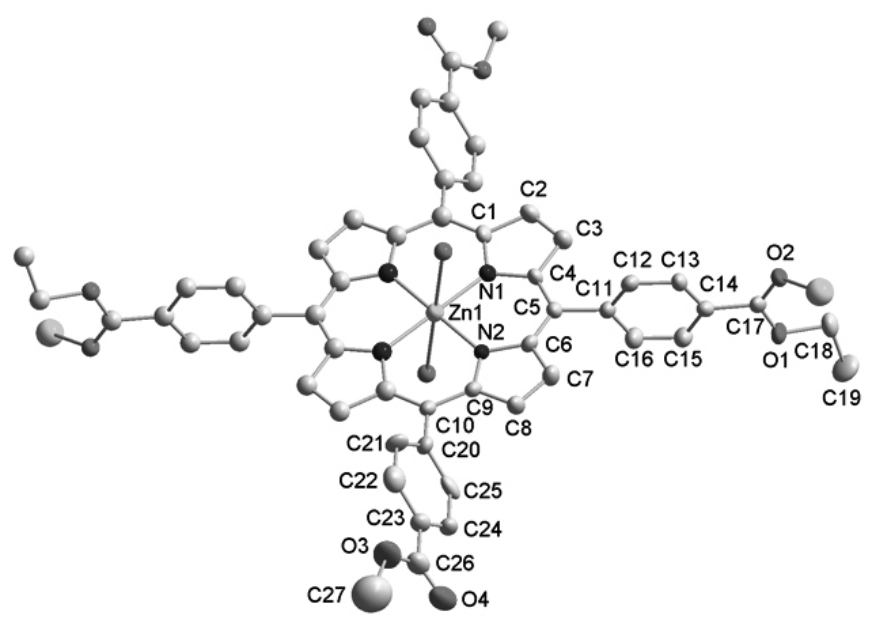

Fig. 1. ORTEP drawing of 1 with $30 \%$ thermal ellipsoids. Hydrogen atoms are omitted for clarity.

The macrocyclic core 24-membered ring of TCPP is nearly coplanar and the displacement of the atoms in the equatorial mean plane is within \pm 0.087 $\AA$. The six-coordinated zinc ion resides at the center of the almost coplanar porphyrin macrocycle, coordinating with four nitrogen atoms and two oxygen atoms to form a slightly distorted octahedron (Fig. 1). The bond distances of

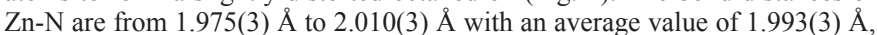
which is comparable with that reported in the literature. ${ }^{16,17}$ The bond lengths of $\mathrm{Zn}-\mathrm{O}$ is $2.628(2) \AA$ which is close to those documented previously..$^{18}$ The result of bond valence calculation shows that the zinc ion has a +2 oxidation state [Zn(1): 2.33]. The phenyl groups are almost perpendicular to the 24-membered macrocycle. The dihedral angles between the macrocycle and the phenyl groups are $55.5(4)^{\circ}$ and $89.3(8)^{\circ}$, respectively. Each $\mathrm{Zn}\left[\mathrm{TCPP}\left(\mathrm{CH}_{2} \mathrm{CH}_{3}\right)_{2}\left(\mathrm{CH}_{3}\right)_{2}\right]$ unit connects to four neighboring ones via $\mathrm{Zn}-\mathrm{O}$ bonds, yielding a condensed 2-D coordination polymer assembly in a herring-bone mode, as shown in Fig. 2.

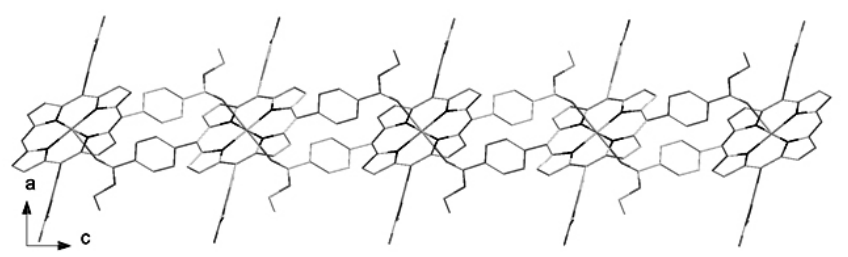

(a)

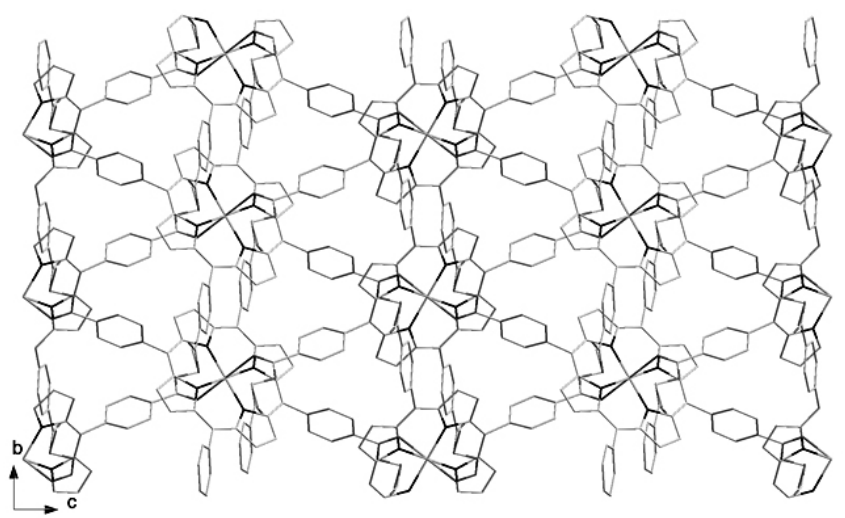

(b)

Fig. 2. The 2-D layer of 1 viewed along the $b$ axis (a) and $a$ axis (b).

It should be pointed out that compound $\mathbf{1}$ displays a large void space being $220 \AA^{3}$ that is $4.6 \%$ of the unit-cell volume, as shown in Fig. 3. There is not necessary to incorporate any counter anions into the large voids of compound 1 because the charge keeps balance. 


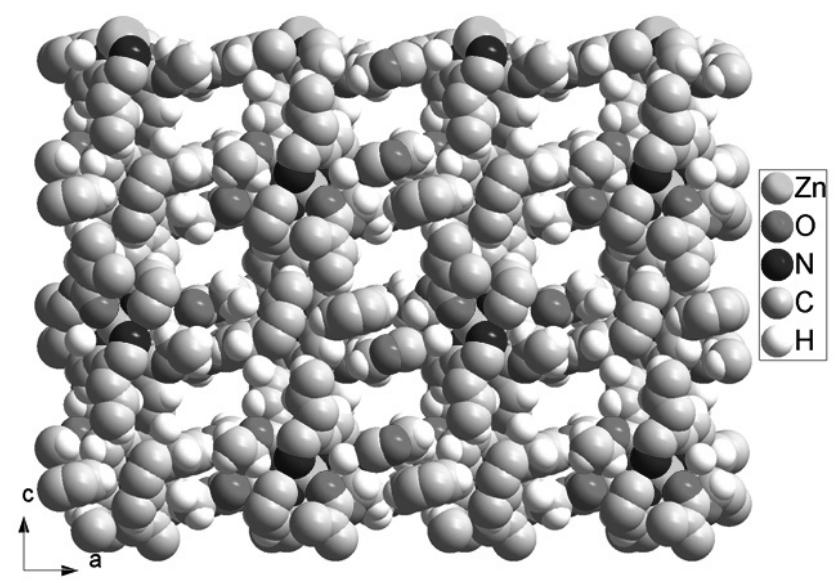

Fig. 3. Space-filling illustration of the porous crystalline architecture of $\mathbf{1}$.

To our knowledge, up to date only some complexes with both TCPP and ester groups have been reported and for many cases the ester groups came from the starting reagents. ${ }^{19,20}$ In order to reveal the reaction mechanism of preparing compound $\mathbf{1}$, we put forward the following logical process: firstly, the TCPP underwent a deprotonation step, then a metalation procedure, finally esterification (Scheme 1). It is noteworthy that compound $\mathbf{1}$ is the first example of porphyrins esterified with ethanol and methanol at the same time. This work offers an effective method to the esterification of a porphyrin.

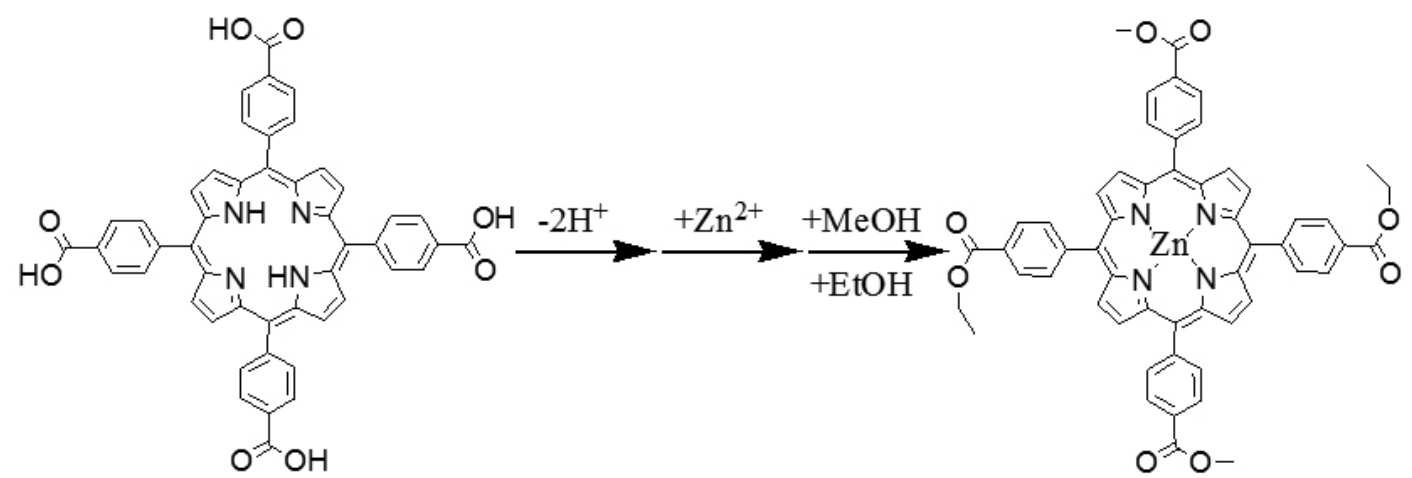

Scheme 1. A schematic diagram for the reaction mechanism of $\mathbf{1}$.

Single-crystal X-ray diffraction analysis discovers that compound 2 is characteristic of an isolated structure, consisting of neutral $\mathrm{TCPP}\left(\mathrm{CH}_{3}\right)_{4}$ molecules. Compound $\mathbf{2}$ crystallizes in the space group $P 2_{1} / c$ of the monoclinic system with two formula units in one cell. All the crystallographic independent atoms locate at general position. An ORTEP drawing of $\mathbf{2}$ with $30 \%$ thermal ellipsoids is shown in Fig. 4. The macrocyclic core 24-membered ring of TCPP is almost coplanar and the displacement of the atoms in the equatorial mean plane is in the range of $-0.035 \AA-+0.035 \AA$. The phenyl groups are not perpendicular to the 24-membered macrocycle. The dihedral angles between the macrocycle and the phenyl groups are $60.84^{\circ}$ and $67.72^{\circ}$, respectively. The TCPP $\left(\mathrm{CH}_{3}\right)$ molecules are solidified by van der Waals interaction to give a crystal packing structure, as shown in Fig. 5.

The FT-IR spectrum of TCPP shows that the bands mainly locate in the range of 700-1700 $\mathrm{cm}^{-1}$, as shown in Fig. 6. The vibration bands at $\sim 3318 \mathrm{~cm}^{-1}$ and $\sim 964 \mathrm{~cm}^{-1}$ are attributed to the $v_{\mathrm{N}-\mathrm{H}}$ and $\delta_{\mathrm{N}-\mathrm{H}}$ vibrations of pyrrole rings. These two bands suggest that the nitrogen atoms are non-coordinated, which is in good agreement with the crystal structure. The strong vibration bands residing at around $1605 \mathrm{~cm}^{-1}$ and $1404 \mathrm{~cm}^{-1}$ are assigned to the asymmetric and symmetric stretching vibration of the carboxylate group.

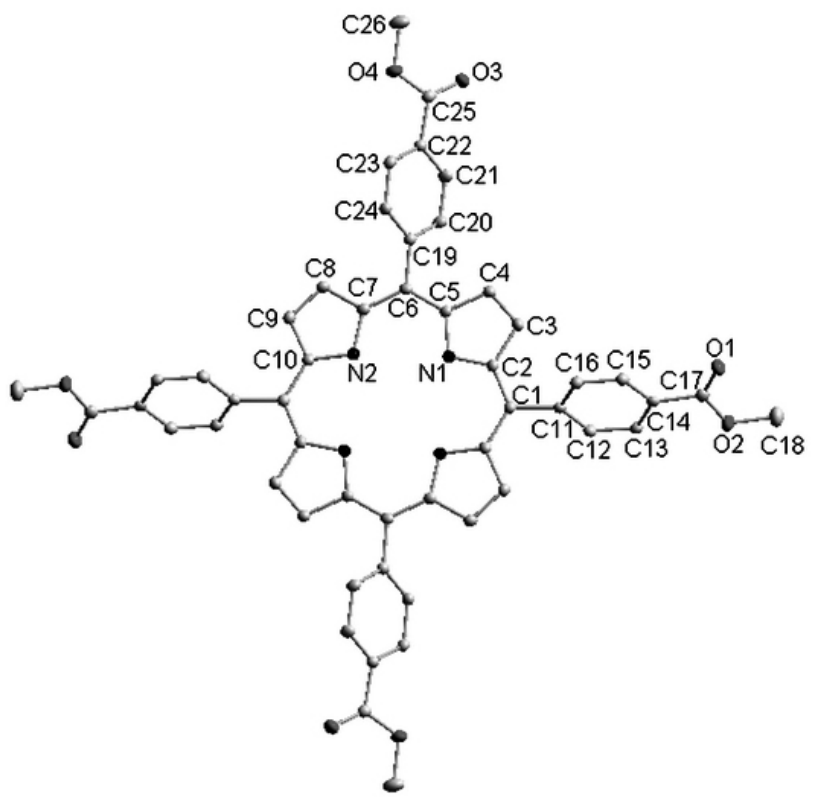

Fig. 4. ORTEP drawing of $\mathbf{2}$ with $30 \%$ thermal ellipsoids. Hydrogen atoms are omitted for clarity. 


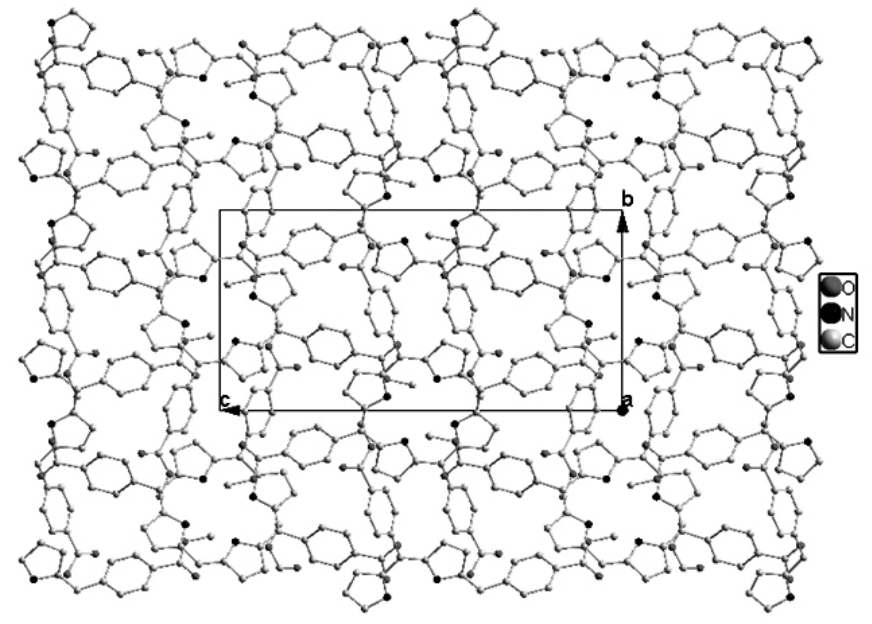

Fig. 5. Crystal packing of 2 .

The reaction mechanism of preparing compound $\mathbf{2}$ is similar to that of compound 1, as presented in Scheme 2.

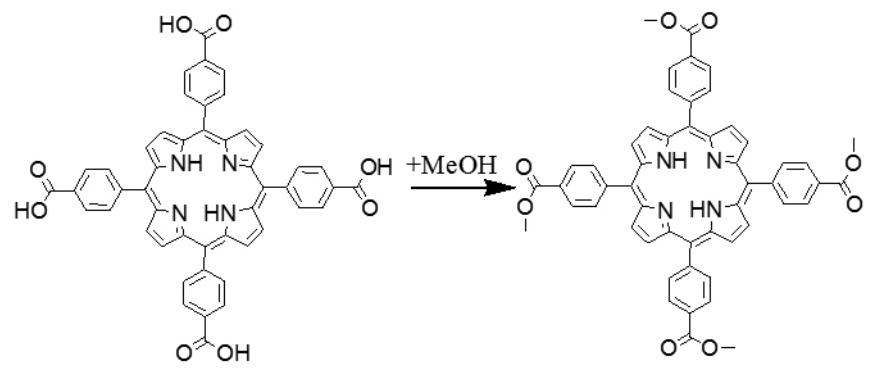

Scheme 2. A schematic diagram for the reaction mechanism of $\mathbf{2}$.

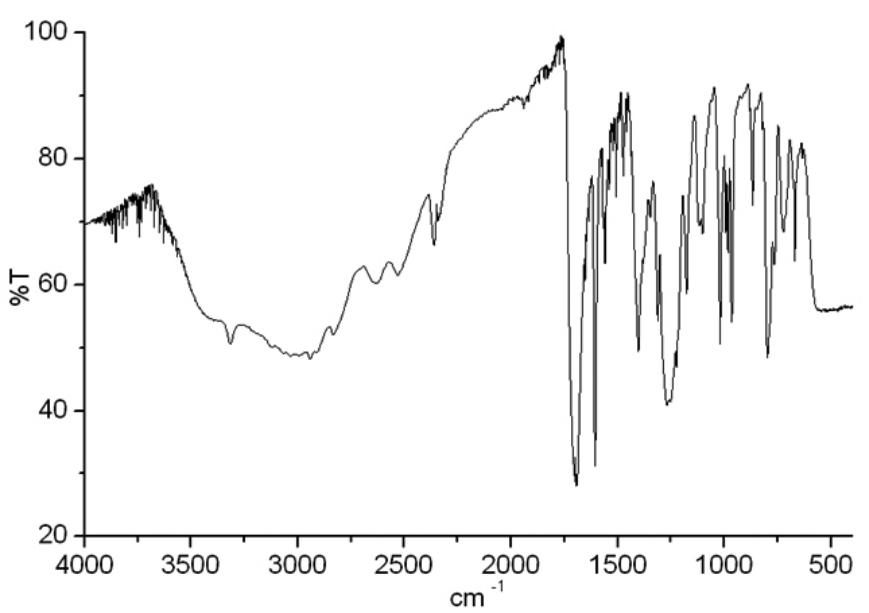

Fig. 6. FT-IR spectrum of TCPP.

Fig. 7 displays the UV-vis absorption spectrum of TCPP measured at room temperature. To our knowledge, porphyrinic compounds can generally display two kinds of absorption bands, i.e. one intensive Soret band (B band) at 400 $\mathrm{nm}$ and several weaker Q bands at around $500-650 \mathrm{~nm}$. The Soret band of TCPP is found at $416 \mathrm{~nm}$, while its Q-bands are observed at 512, 546, 590 and $645 \mathrm{~nm}$. The number of Q bands is four which is larger than two, indicating that the nitrogen atoms are non-coordinated, which is also in good agreement with the crystal structure.

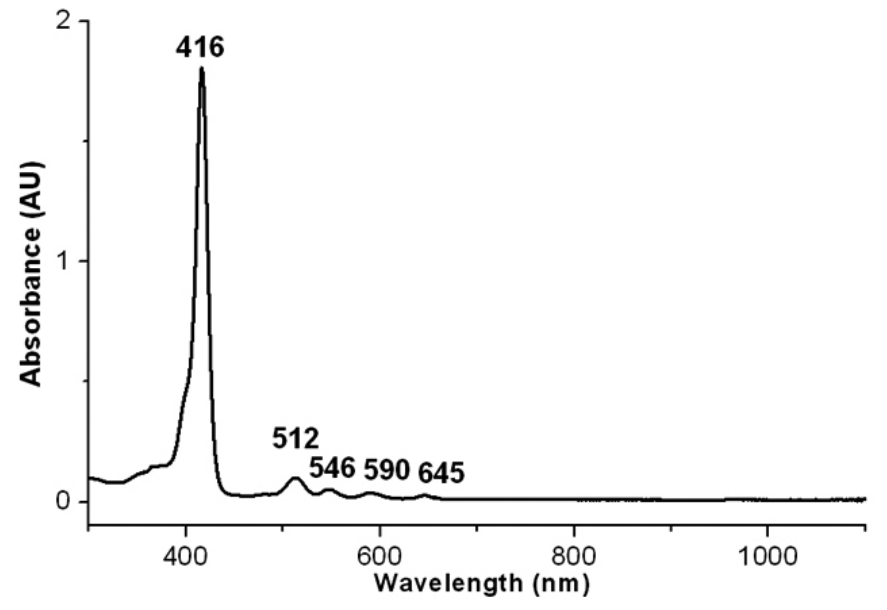

Fig. 7. UV-vis absorption spectrum of TCPP measured at room temperature.

Generally, solid-state porphyrinic compounds do not exhibit photoluminescence due to the concentration quenching effect. However, if porphyrinic compounds were dissolved in solution, they can usually display bright red emission. The photoluminescence spectra of TCPP measured in ethanol at room temperature are presented in Fig. 8. The photoluminescence spectra reveal that the effective energy absorption is mainly resided in the wavelength region of 400-600 $\mathrm{nm}$. The excitation spectrum under the emission of $650 \mathrm{~nm}$ shows four bands at 432, 519, 548 and $589 \mathrm{~nm}$. We also measured the corresponding emission spectrum with the use of an excitation wavelength of $589 \mathrm{~nm}$. We find that the emission spectrum displays a strong emission band at $650 \mathrm{~nm}$ with a shoulder peak at $710 \mathrm{~nm}$. The photoluminescence quantum yield of TCPP in ethanol was determined to be 0.044 . By using a time-correlated single photon counting technique, the fluorescence lifetime in ethanol was performed upon the excitation wavelength of $421 \mathrm{~nm}$. The decay of the singlet-excited states was fitted as single exponential, from which the fluorescence lifetime of TCPP is $0.17 \mathrm{~ns}$.

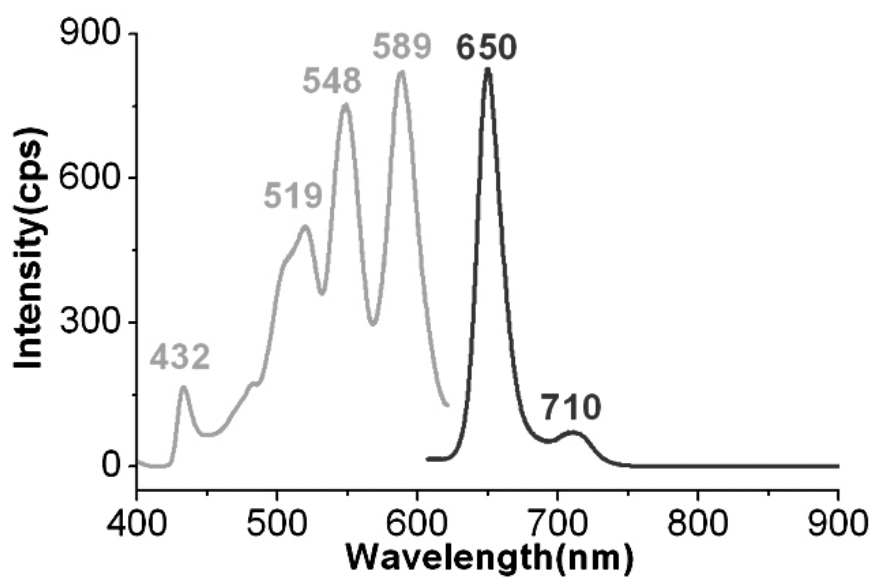

Fig. 8. Photoluminescence spectra of TCPP. Green: excitation; red: emission.

\section{CONCLUSIONS}

In conclusion, two novel porphyrinic compounds, $\left\{\mathrm{Zn}\left[\mathrm{TCPP}\left(\mathrm{CH}_{2} \mathrm{CH}_{3}\right)_{2}\left(\mathrm{CH}_{3}\right)_{2}\right]\right\}$ (1) and TCPP $\left(\mathrm{CH}_{3}\right)_{4}(\mathbf{2})(\mathrm{TCPP}=$ meso-tetra $(4-$ carboxyphenyl)porphyrin), with the $\operatorname{TCPP}\left(\mathrm{CH}_{2} \mathrm{CH}_{3}\right)_{2}\left(\mathrm{CH}_{3}\right)_{2}$ and $\operatorname{TCPP}\left(\mathrm{CH}_{3}\right)_{4}$ generated in situ, have been synthesized and characterized. Compound $\mathbf{1}$ is characteristic of a 2-D coordination polymer, based on the zinc ion coordinating to four nitrogen atoms and two oxygen atoms. Compound $\mathbf{1}$ possesses a large void space $\left(220 \AA^{3}\right)$. Compound $\mathbf{2}$ is characterized by an isolated structure. The reaction mechanism of preparing both compounds was explored. The 
photoluminescence properties, FT-IR, UV-vis absorption spectra, fluorescence lifetime and fluorescence quantum yield of TCPP were also reported in this paper. To gain deeper insight into the synthetic methodology, future study in our laboratory will aim at preparing novel porphyrinic compounds.

\section{ACKNOWLEDGMENTS}

We gratefully acknowledge the financial support of the NSF of China (21565016, 21361013), Jiangxi Provincial Science and Technology Support Key Project (20152ACG70021), Jiangxi Provincial Natural Science Foundation (20142BAB205062), Jiangxi Provincial Department of Education's Item of Science and Technology(GJJ150761), Jinggangshan University Natural Science Item (JZ0813), the open foundation (ST201522007) of the Key Laboratory of Jiangxi Province for Persistant Pollutants Control and Resources Recycle (Nanchang Hangkong University), and the open foundation (20150019) of the State Key Laboratory of Structural Chemistry, Fujian Institute of Research on the Structure of Matter, Chinese Academy of Sciences.

\section{REFERENCES}

1.- Lu J. Y.. Coord. Chem. Rev., 246, 327-347 (2003).

2.- Chen X. M., Tong M. L.. Acc. Chem. Res., 40, 162-170 (2007).

3.- Benny P. D., Fugate G. A., Barden A. O., Morley J. E., Silva-Lopez E., Twamley B.. Inorg. Chem., 47, 2240-2242 (2008).

4.- Chen W.-T.. J. Chem. Res., 405-407 (2011).

5.- Chen W.-T., Hu L.. Acta Chim. Slov., 58, 167-170 (2011).

6.- Chen W.-T., Liu D.-S., Luo Z.-G., Chen H.-L., Liu J.-H.. J. Chem. Res., 491-493 (2011).
7.- Silva A. M. G., Tomé A. C., Neves M. G. P. M. S., Cavaleiro J. A. S.. Tetrahedron Lett., 41, 3065-3068 (2000).

8.- Tomé A. C., Lacerda P. S. S., Neves M. G. P. M. S., Cavaleiro J. A. S.. Chem. Commun., 1199-1200 (1997).

9.- Cavaleiro J. A. S., Neves M. G. P. M. S., Tomé A.C.. Arkivoc, 14, $107-$ 130 (2003).

10.- Chen W.-T., Liu D.-S., Xu Y.-P., Luo Q.-Y., Pei Y.-P.. Luminescence, 31, $158-163$ (2016).

11.- Zhang X., Chen W.-T., Suenobu T., Fukuzumi S., Wang M.-S., Guo G.-C.. J. Porphyr. Phthalocya., 19, 1225-1231 (2015).

12.- Pei Y.-P., Huang J.-G., Chen H.-L., Kuang H.-M., Zhou J., Yang Y.-X., Chen W.-T.. J. Porphyr. Phthalocya., 19, 1140-1146 (2015).

13.- Chen W.-T., Huang J.-G., Lei X.-Y., Hu R.-H., Pei Y.-P., Yang Y.-X., Zhou J.. J. Iran. Chem. Soc., 13, 95-101 (2016).

14.- Rigaku, CrystalClear Version 1.35, Rigaku Corporation, Tokyo, Japan (2002).

15.- Siemens, SHELXTL ${ }^{\mathrm{TM}}$ Version 5 Reference Manual, Siemens Energy \& Automation Inc., Madison, Wisconsin, USA (1994).

16.- Shultz D. A., Mussari C. P., Ramanathan K. K., Kampf J. W.. Inorg. Chem., 45, 5752-5759 (2006).

17.- Gros C. P., Brisach F., Meristoudi A., Espinosa E., Guilard R., Harvey P. D.. Inorg. Chem., 46, 125-135 (2007).

18.- Yang F.-A., Guo C.-W., Chen Y.-J., Chen J.-H., Wang S.-S., Tung J.-Y., Hwang L.-P., Elango S.. Inorg. Chem., 46, 578-585 (2007).

19.- Muniappan S., Lipstman S., Goldberg I.. Acta Crystallogr., Sect. C., 62, m495-m497 (2006).

20.- Muniappan S., Lipstman S., Goldberg I.. Acta Crystallogr., Sect. C., 62, $\mathrm{m} 140-\mathrm{m} 143$ (2006). 